Article

\title{
Environmental and Health: The Importance of Tremolite Occurence in the Pollino Geopark (Southern Italy)
}

\author{
Maria Carmela Dichicco ${ }^{1}$ (D), Salvatore Laurita ${ }^{1}$, Rosa Sinisi ${ }^{1}$ (D), Raimondo Battiloro ${ }^{1,2}$ \\ and Giovanna Rizzo ${ }^{1, *(1 D)}$ \\ 1 Department of Sciences, University of Basilicata, 85100 Potenza, Italy; maria.dichicco@unibas.it (M.C.D.); \\ salvatorelaurita@hotmail.it (S.L.); rosa.sinisi@unibas.it (R.S.); raimondobattiloro@tiscali.it (R.B.) \\ 2 U.O.C. di Pneumologia, Azienda Ospedaliera San Carlo, 85100 Potenza, Italy \\ * Correspondence: giovanna.rizzo@unibas.it; Tel.: +39-0971-205-833
}

Received: 24 January 2018; Accepted: 8 March 2018; Published: 13 March 2018

\begin{abstract}
Worldwide studies have been done about the toxicity and carcinogenicity of asbestos minerals occurring in ophiolitic rocks. Inhalation of asbestos due to environmental exposure could cause malignant mesothelioma and lung cancers. In particular, the ophiolitic rocks in Tethyan realm represents a serious enivironmental concern due to both the presence of asbestos-like minerals and the large $\mathrm{Cr}$ abundance that is prone to solubilisation as CrVI. At the Pollino Geopark (southern Apennines, Italy), serpentinites-rich ophiolite rocks and sediments of the Frido Unit crop-out. In these rocks, tremolite, an asbestos-like mineral, is typically intergrown with fibrous antigorite and chrysotile. Tremolite shows acicular, friable, fibrous, and elongated habitus, can be easily released into the environment as a result of both natural processes and anthropogenic activities. In the analyzed rocks, tremolite is present mainly in veins as much as in the matrix and forms crowns around clinopyroxene porphyroclasts. The different analytical techniques showed the recognition of the amphibole-like minerals (actinolite and tremolite) that are the dominant phases, with a small percentage of $\mathrm{Fe}^{2+}$. The presence of Fe in the "ideal" tremolite asbestos could cause pathological effects for the human living in the Pollino Geopark. This study has several environmental relevant implications, including, for example, the realization of national health protecting programs and the mapping of natural sites characterized by the presence of asbestos minerals in Pollino Geopark and in others area where outcrop asbestos bearing ophiolitic rocks.
\end{abstract}

Keywords: asbestos minerals; environmental implications; tremolite; serpentinite rocks; pleural mesothelioma

\section{Introduction}

This study concerns the investigation of asbestiform amphiboles coming from serpentinites of the Frido Unit (Pollino Geopark, southern Apennines). Serpentinites may contain amounts of asbestiform and other fibrous minerals, causing possible health problems due to fibre exposure [1]. Major mineral element as Fe, and some trace metal elements may play a role in fibre toxicity [2]. Furthermore, the weathering of outcrops of ultramafic rocks release chemical elements into groundwater, for example, the CrVI [3] where toxic elements may accumulate and result in human exposures.

Several authors ascribe the fibres toxicity to their morphology and size, chemical-physical characteristics, surface reactivity, and biopersistence [4]. The regulated asbestos fibres (chrysotile and amphiboles) correspond to fibres definite breathable by the WHO (World Health Organization, Geneva, Switzerland), having length $>5 \mu \mathrm{m}$, width $<3 \mu \mathrm{m}$ and ratio $>3$ [5-8]. 
The definition of asbestos used by regulatory agencies for identification includes the following six mineral species: chrysotile, crocidolite, amosite, tremolite, actinolite, and anthophyllite $[9,10]$. Among these minerals only chrysotile is a sheet silicate; the other minerals are included within the amphibole group.

The amphibole structure consists of two principal elements: a double chain of corner-sharing tetrahedral and a strip of edge-sharing octahedral, both of which extend in the c-direction. Six structural types of amphibole have been recognized [11]. Their general chemical formula can be written as $\mathrm{AB}_{2} \mathrm{C}_{5} \mathrm{~T}_{8} \mathrm{O}_{22} \mathrm{~W}_{2}$ where: $\mathrm{A}=$ vacant, $\mathrm{Na}, \mathrm{K}, \mathrm{Ca}, \mathrm{Li} ; \mathrm{B}=\mathrm{Na}, \mathrm{Li}, \mathrm{Ca}, \mathrm{Mn}^{2+}, \mathrm{Fe}^{2+}, \mathrm{Mg} ; \mathrm{C}=\mathrm{Mg}$, $\mathrm{Fe}^{2+}, \mathrm{Mn}^{2+}, \mathrm{Al}, \mathrm{Fe}^{3+}, \mathrm{Mn}^{3+}, \mathrm{Ti}^{4+}, \mathrm{Li} ; \mathrm{T}=\mathrm{Si}, \mathrm{Al}, \mathrm{Ti}^{4+} ; \mathrm{W}=(\mathrm{OH}), \mathrm{F}, \mathrm{Cl}, \mathrm{O}^{2-}$. Minor elements, such as $\mathrm{Zn}, \mathrm{Ni}^{2+}, \mathrm{Co}^{2+}, \mathrm{V}^{3+}, \mathrm{Sc}, \mathrm{Cr}^{3+}$, and $\mathrm{Zr}$ are also observed as $\mathrm{C}$ cations [2]. The calculation of the crystal-chemical formula of the amphibole can be performed when assuming a content of 24 anions or 23 atoms per unit formula (apfu) [11]. Tremolite is a monoclinic calcic amphibole with ideal formula $\mathrm{Ca}_{2} \mathrm{Mg}_{5} \mathrm{Si}_{8} \mathrm{O}_{22}(\mathrm{OH})_{2}$ that represents the $\mathrm{Mg}$ end member of the tremolite, actinolite, ferro-actinolite series (hereinafter actinolite series) consisting of clino-amphiboles common in greenschist to amphibolite facies ultrabasic rocks [12]. The actinolite series is subdivided on the basis of ferro-actinolite content (calculated by the $[(\mathrm{Fe}+\mathrm{Mn}) /(\mathrm{Fe}+\mathrm{Mn}+\mathrm{Mg})$ ratio] into tremolite $(0-10 \%$ ferro-actinolite), actinolite (10-50\% ferro-actinolite), and ferro-actinolite (50-100\% ferro-actinolite), highlighting the common presence of crystals with intermediate compositions whose identification is difficult and is based only on their crystal chemistry [8]. Crystal chemical characterization of fibrous amphibole is extremely relevant for environmental and health issues. In fact, the regulation applies only to fibres that fit the compositional definition of the actinolite series [13]. This paper focuses on the identification and mineralogical investigation of tremolite fibres within serpentinite rocks. Results of a well-tested $\backslash$ multi-analytical approach, including X-ray powder diffraction analysis (XRPD), $\mu$-Raman spectroscopy, Fourier Transform InfraRed Spectroscopy (FT-IR), Electron Microprobe Analysis (EMPA), and Scanning Electron Microscopy with Energy Dispersive Spectroscopy (SEM-EDS), are presented and discussed in order to new data for the realization of health protecting measures, especially in people that are living in proximity of naturally occurring asbestos source and/or having a directly contact with asbestos during human activities, such as road construction and quarry excavations. Furthermore, these results may provide new information for the compulsory Italian mapping of natural sites that are characterized by the presence of the asbestos in its natural setting.

\section{Environmental and Toxicological Relevance}

It has been known since the early of XX century that chronic asbestos fiber inhalation may cause a slow and progressive diffuse interstitial pulmonary illness known with the term of "Asbestosis". In 1997, the International Expert Meeting on Asbestos, Asbestosis, and Cancer estimated that around 10,000 Malignant Mesothelioma and 20,000 lung cancer cases occur in specific area, as well as Western Europe, North America, Japan and Australia [14].

In the Pollino Geopark, many cases of mesothelioma were documented [15]. The Regional Operating Centres of Basilicata (COR) along with the Italian National Mesothelioma Register (ReNaM) conducted in this area a wide-ranging epidemiological study whose results ascribed 17/90 mesothelioma cases to environmental factors, such as the exposure of people to naturally outcropping asbestos-bearing rocks [16]. Asbesto minerals are constituted from flexible, heat-resistant, and chemically inert fibrous. When inhaled, they can cause neoplasms with a high mortality rate as asbestosis, lung cancer, and malignant mesothelioma [5-8]. Asbestos fibers penetrate partially in the lung interstitial at respiratory and alveolar bronchial levels, causing alveolite phenomena with microemorrhages, small outbreaks of alveolar and interstitial edema. The pathognomonic histologic finds consist of asbestos corpuscles, interstitial or endoalveolar, consisting of asbestos fibers of 15-100 $\mu \mathrm{m}$ length, wrapped in a protein-containing mantle containing iron. On the pathogenic pathway, it is assumed that damage mechanisms follow this scheme: (a) chemical action of tissue fluid on asbestos fibers with release of silicic acid; (b) irritative-mechanical action; and, (c) formation of 
specific response antigens and formation of asbestos bodies [17]. Among these, malignant pleural mesothelioma is an uncommon neoplasm typically originating by chrysotile, crocidolite, amosite, or tremolite that are considered to be the most dangerous carcinogen fibers, this is associated to inhalation of fluoro-edenite and erionite fibers [18]. Furthermore, the presence in the fiber structure of cations such as $\mathrm{Fe}, \mathrm{Ni}$, and $\mathrm{Ti}$, even in small amounts, may affect their physico-chemical properties [2,19-21]. In particular, the presence of Fe, the structural coordination, and furthermore, the Fe exposed on the fiber surface are important factors in the reactive oxygen species (ROS) production. According to in vitro studies on biological system-mineral interactions, the impurities and the size are considered to be responsible for the pathological effects [22-25]. Toxicological studies on the interactions between bronchoalveolar fluids and inhaled atmospheric particulate [26,27] indicated that the metallic elements are released and accumulate in the human organs, producing different health effects [28]. Furthermore, several researches have been demonstrated the strong linkage between mesothelioma and a series of environmental factors, such as the exposure to asbestos minerals, especially in people that are living in proximity of naturally occurring asbestos sources and/or having a direct contact with asbestos [18,29-31]. This is because asbestos-bearing rocks, chiefly serpentinites, can release significant amounts of fibres into the air, water, and soil, notably, both weathering processes and human activity (ore mining, grinding, and milling) can separate the fibres into smaller fibrils that are widely spread out into the environment, and are therefore easily inhalable.

\section{Geological Outline}

The ophiolitic rocks of the Frido Unit (Pollino Geopark, southern Apennines) are well exposed and consist of the asbestos-bearing serpentinites and minor metagabbros, metabasalt, diabase rocks and their sedimentary cover [32-34] and associate with shales, calcschists and metalimestones and continental crust rocks [35-37]. Slivers of continental crust with ophiolites [6,8,33,38-42] occur as a thrust fault delimiting the upper portion of the Frido Unit from a lower portion. The serpentinites outcrop in several active and abandoned quarries (Figure 1) and were represented by the lherzolitic to harzburgitic $[43,44]$, upper mantle basement of the Internal Liguride sequence consisting of Neotethyan Ocean fragments uplifted during the formation of the Appenine [26,45-47]. Serpentinites are cross-cut by mafic dykes and medium to high-grade metamorphic rocks (amphibolite, gneiss, granofels, gabbro and pillow lava basalts) $[43,44,48]$. Serpentinites show two major phases of ocean floor polyphase metamorphism $[43,44,48]$, during which ductile deformation, recrystallization, and hydrothermal metasomatism processes favouring the formation of the fibrous minerals [49].

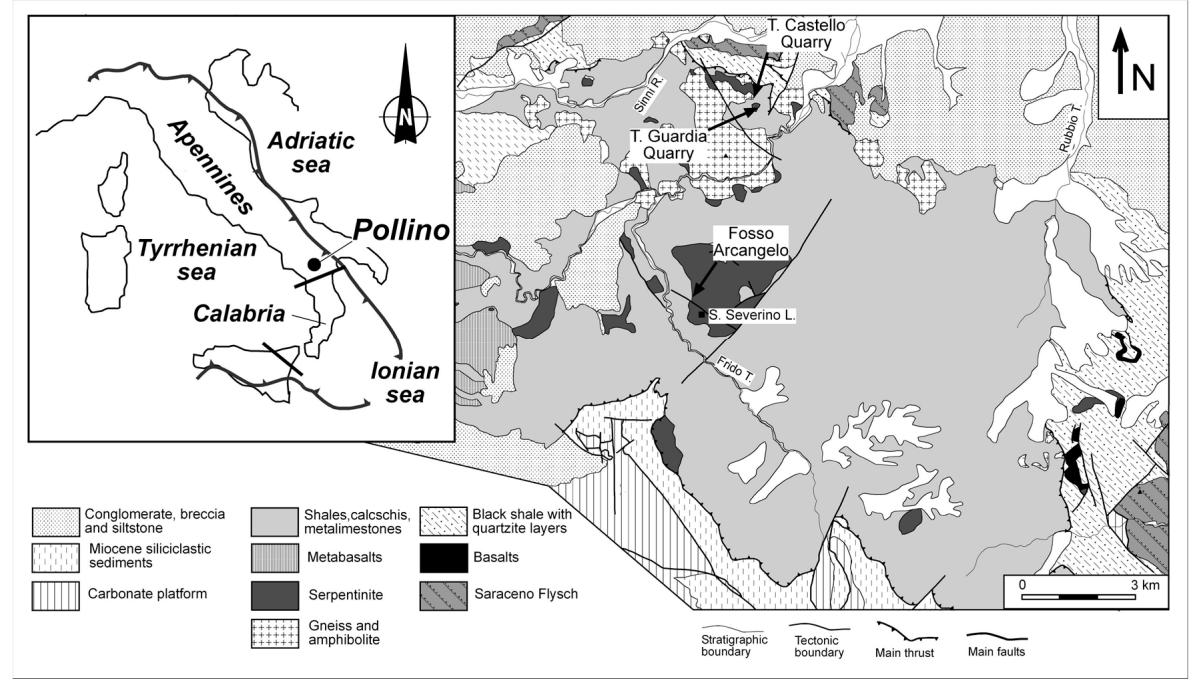

Figure 1. Geological sketch map of the southern Apennines and location of the study area. 


\section{Sampling}

The Frido Unit serpentinites were collected at the Fosso Arcangelo site, which is located close to the San Severino Lucano village (Figure 1). As recently documented by [50] the serpentinite rocks can be classified as cataclastic and massive. Cataclastic serpentinites show high degree of fracturing and deformation that form cohesive serpentinites and / or fault breccias. The fractures are almost completely filled by exposed white and grey fibrous minerals [51]. Two fiber types have been identified in the outcrops: (1) big and elongate fibers developed over slickensided surfaces; and, (2) very fine-grained fibers forming a network pervading the whole rock. Massive serpentinites show a low fracturing and deformation degree and any exposed fibrous minerals. Though the cataclastic and massive serpentinites have homogeneous mineral compositions [51].

\section{Analytical Methods}

\subsection{X-Ray Powder Diffraction}

All of the samples were powdered in a Retsch RS 100 planetary mill equipped with four agate jars and agate milling balls to generate a very fine powder suitable for mineralogical analysis, using a cooker hood 701 EXHAUST HEPA laminar flow capable to remove all the small and read fibres and protective clothing to prevent any contamination. The XRPD analyses were performed at the Department of Sciences, University of Basilicata, on randomly oriented powdered samples, using a Siemens D5000 powder diffractometer, $\mathrm{CuK} \alpha$ radiation, $40 \mathrm{kV}$, and $32 \mathrm{~mA}$. Data were recorded between $5^{\circ}$ and $70^{\circ} 2 \theta$ with step size of $0.02^{\circ}$ and scan speed of $2 \mathrm{~s}$, in order to optimize the signal/noise ratio. The mineral identification was realized by mean of X'Pert HighScorePlus software (Panalytical, 2001) using the PDF-2 (2005) database.

\section{2. $\mu$-Raman Spectroscopy}

The Raman spectroscopy measurements were performed on rock slabs obtained by a cutting machine hermetically sealed and waterjet to prevent the dispersion of fibres in the surrounding environment. The Raman analysis were carried out at the Department of Sciences, University of Basilicata, Potenza, using a Horiba Jobin-Yvon LabRam HR800 spectrometer equipped with a HeNe laser source with a wavelength of $633 \mathrm{~nm}$, a CCD detector operating at $-70{ }^{\circ} \mathrm{C}$, and an edge filter that exclude from detection shift below $150 \mathrm{~cm}^{-1}$. A spectral resolution of $4 \mathrm{~cm}^{-1}$ was obtained by a holographic grating with 600 lines $/ \mathrm{mm}$. Correct calibration of the instrument was verified checking the position of the Si band at $\pm 520.7 \mathrm{~cm}^{-1}$. Output laser power was $20 \mathrm{mV}$, and measurements were performed using optical microscope Olympus with objective of 10x, 50x and 100x. A laser beam spatial resolution of $1 \mu \mathrm{m}$ was obtained with the 100x objective. Spectra result from the average of five acquisitions of $10 \mathrm{~s}$ to optimize the signal/noise ratio. Two regions of the Raman spectra were investigated: $1200-150 \mathrm{~cm}^{-1}$ for the characterization of structural bonding and $3800-3500 \mathrm{~cm}^{-1}$ for the identification of the hydroxyl groups. Amphibole minerals were identified on the basis of data reported in [52] and in the RUFF online free-database.

\subsection{Electron Microprobe Analyses}

Electron microprobe analyses were performed on the polished thin sections at the Department of Earth Sciences, University of Calabria (Arcavacata di Rende, Cosenza, Italy), using a JEOL JXA 8200 probe, equipped with five WDS spectrometers and an EDS spectrometer. The analytical conditions were excitation voltage $15 \mathrm{kV}$, specimen current $10 \mathrm{nA}$, beam diameter $1 \mu \mathrm{m}$, count time (peak) $30 \mathrm{~s}$, count time (background) $5 \mathrm{~s}$. The following standards were used: $\mathrm{Na}, \mathrm{Al} \mathrm{Si}=$ Jadeite; $\mathrm{Mg}, \mathrm{Ca}=$ Diopside; $\mathrm{Fe}$, $\mathrm{Cr}, \mathrm{Mn}=$ metal. 


\subsection{Scanning Electron Microscopy and Microanalysis EDS}

SEM-EDS analyses were performed on the polished thin sections at the Department of Biology, Ecology, and Earth Sciences, University of Calabria (Arcavacata di Rende, Cosenza, Italy), using a FEI/Philips scanning microscope with GENESIS 4000 EDAX X-ray system based on a Si/Li crystal detector. Analytical conditions were $15 \mathrm{kV}$ accelerating voltage and $600 \mathrm{pA}$ beam current.

\subsection{Fourier Transform InfraRed Spectroscopy}

Fourier transform infrared spectroscopy measurements were carried out at the Department of Sciences, University of Basilicata. Samples were prepared by dispersing $1 \mathrm{mg}$ of powdered rock into $450 \mathrm{mg}$ of $\mathrm{KBr}$. The homogenized mixture was subsequently pressed under vacuum to transparent pellets that are $13 \mathrm{~mm}$ in diameter. The FT-IR spectroscopy has been performed with a Jasco FT-IR 460 Plus interferometer. The spectra have been acquired by collecting 30 scans at $4 \mathrm{~cm}^{-1}$ resolution. Two regions of the Raman spectra were investigated: 2800-400 for structural bonding characterization and 3800-3500 $\mathrm{cm}^{-1}$ for the characterization of the hydroxyl groups. The spectra were displayed in the form of absorbance as a function of wavenumber and were evaluated using the program Origin.

\section{Results and Discussion}

Petrographic characterization shows that the serpentinites are pseudomorphic and vein textures [48]. The serpentinites mainly consist of olivine, pyroxene (orthopyroxene and clinopyroxene), Cr-spinel, serpentine (lizardite, crysotile, antigorite, polygonal serpentine), clinochlore, magnetite, prehnite amphibole, and Fe-hydroxides (Table 1). The first texture is defined by serpentine group minerals [51] + magnetite mesh-texture with a core of relict olivine grains and by bastite pseudomorph after orthopyroxene. The second texture cross-cut the pseudomorphic texture [43,50]. The veins are filled by serpentine and serpentine \pm amphiboles, amphibole minerals (tremolite-actinolite series), calcite \pm amphiboles [50], chlorite, and prehnite [48].

Table 1. GPS coordinates, field feature, texture, and mineral assemblages of the serpentinite samples. Symbols as [53] the exception Prh * = prehnite.

\begin{tabular}{|c|c|c|c|c|}
\hline Samples & GPS Coordinates & Field Characteristic & Texture & Mineral Assemblages \\
\hline S1 & $\begin{array}{c}40^{\circ} 01^{\prime} 40.02^{\prime \prime} \\
\mathrm{N}-16^{\circ} 08^{\prime} 07.9^{\prime \prime} \mathrm{E}\end{array}$ & Cataclastic serpentinite & Pseudomorphic and vein & $\begin{array}{l}\text { Srp-Spl-Chl-relics Ol-relics Cpx } \\
\text { and Opx-Op-Am-Prh * }\end{array}$ \\
\hline S4 & $\begin{array}{c}40^{\circ} 01^{\prime} 39.2^{\prime \prime} \\
\mathrm{N}-16^{\circ} 08^{\prime} 09.6^{\prime \prime} \mathrm{E}\end{array}$ & Cataclastic serpentinite & Pseudomorphic and vein & $\begin{array}{l}\text { Srp-Spl-Chl-relics Ol-relics Opx } \\
\text { and Cpx-Am }\end{array}$ \\
\hline S5 & $\begin{array}{c}40^{\circ} 01^{\prime} 39.02^{\prime \prime} \\
\mathrm{N}-16^{\circ} 08^{\prime} 09.6^{\prime \prime} \mathrm{E}\end{array}$ & $\begin{array}{l}\text { Cataclastic serpentinite cut } \\
\text { by carbonate veins }\end{array}$ & $\begin{array}{l}\text { Pseudomorphic and } \\
\text { brecciated-vein }\end{array}$ & $\begin{array}{c}\text { Srp-Chl-relics Cpx and } \\
\text { Opx-Am-Cal-Op }\end{array}$ \\
\hline S6.2 & $\begin{array}{c}40^{\circ} 01^{\prime} 38.3^{\prime \prime} \\
\mathrm{N}-16^{\circ} 08^{\prime} 10.4^{\prime \prime} \mathrm{E}\end{array}$ & Cataclastic serpentinite & Pseudomorphic & Srp-Spl-relics Ol-relics Cpx-Am \\
\hline S7 & $\begin{array}{c}40^{\circ} 01^{\prime} 37.6^{\prime \prime} \mathrm{N}-16^{\circ} \\
08^{\prime} 10.7^{\prime \prime} \mathrm{E}\end{array}$ & Cataclastic serpentinite & Pseudomorphic & Srp-Spl-relics Ol-relics Cpx-Am \\
\hline S27 & $\begin{array}{c}40^{\circ} 01^{\prime} 39.2^{\prime \prime} \\
\mathrm{N}-16^{\circ} 0.8^{\prime} 25.5^{\prime \prime} \mathrm{E}\end{array}$ & Cataclastic serpentinite & Pseudomorphic & Srp-Spl-relics Ol-relics Cpx-Am \\
\hline $\mathrm{S} 30$ & $\begin{array}{c}40^{\circ} 01^{\prime} 45.3^{\prime \prime} \\
\mathrm{N}-16^{\circ} 0.8^{\prime} 27.3^{\prime \prime} \mathrm{E}\end{array}$ & Cataclastic serpentinite & Pseudomorphic & $\begin{array}{l}\text { Srp-Spl-Chl-relics Ol-relics Opx } \\
\text { and Cpx-Am }\end{array}$ \\
\hline
\end{tabular}

The amphibole minerals, being of the tremolite-actinolite series [54], occurs as fine-fibers and are present in veins as much as in the matrix of analyzed rocks also forming crowns around clinopyroxene porphyroclasts. The X-ray diffraction analysis allowed for the recognition of the serpentine and amphibole-like minerals (actinolite, $\mathrm{d}=8.31 \AA$; tremolite, $\mathrm{d}=2.94 \AA$ ) that are the dominant phases, followed by 2:1 phyllosilicate (clinochlore, $\mathrm{d}=4.74 \AA$ ), with minor amount of iron oxides (magnetite, $\mathrm{d}=2.52 \AA$ ) (Figure 2). 


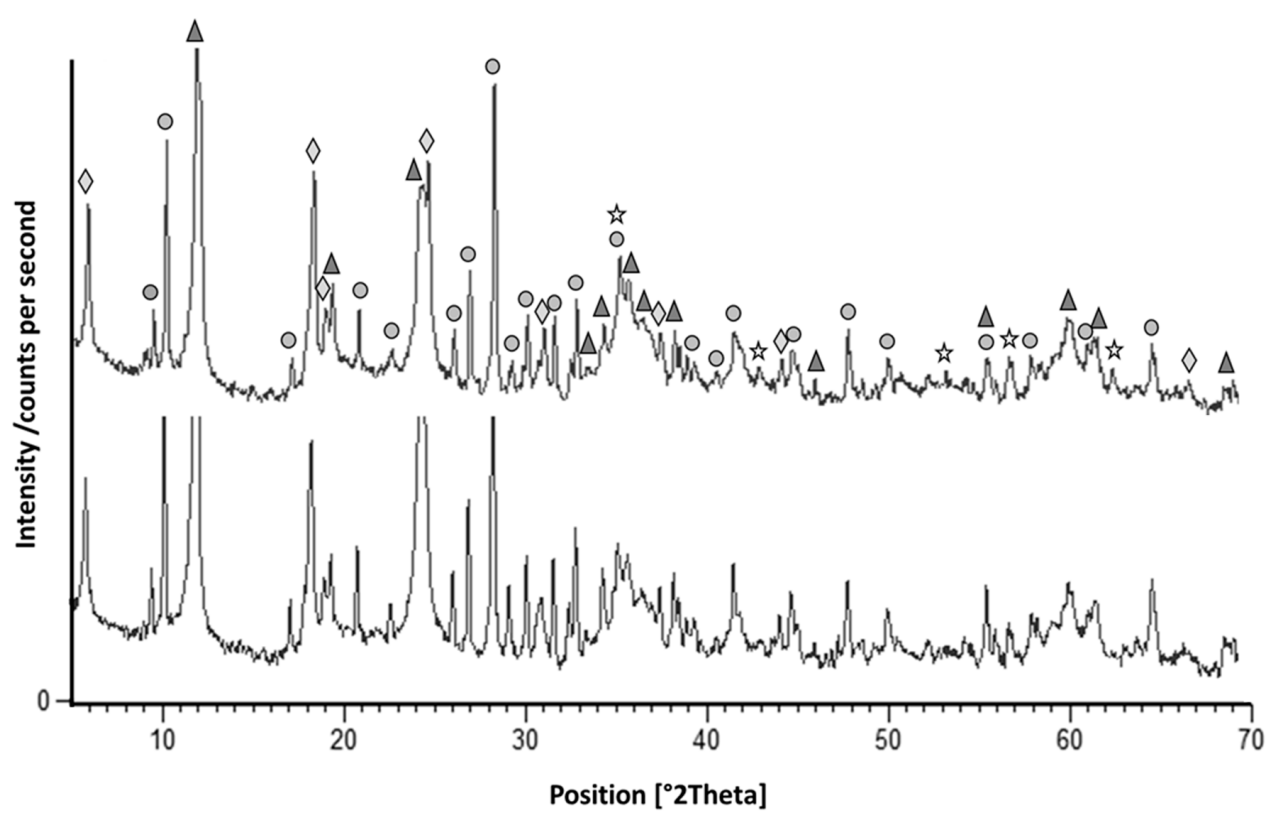

Figure 2. X-ray powder diffraction analysis (XRPD) patterns of selected bulk and vein serpentinite samples. Legend: filled triangle $=$ serpentine; filled circle $=$ tremolite; filled rhombus = clinochlore; star = magnetite.

According with $[50,52,54]$, our spectra, symmetric, and antisymmetric Si-O-Si stretching modes of fibrous amphibole give peaks at about 1062 and $675 \mathrm{~cm}^{-1}$, the second one is also the strongest peak. O-H-O vibrations produce one other strong peaks at about $223 \mathrm{~cm}^{-1}$ (Figure 3a). In the $\mathrm{OH}$ vibrational region, amphibole shows two peaks, the most intense at $3675-3673 \mathrm{~cm}^{-1}(\mathrm{Mg} ; \mathrm{Mg} ; \mathrm{Mg})$, and the second at 3660-3663 $\mathrm{cm}^{-1}$ ( $\mathrm{Mg}$; Mg; Fe) obtained by Raman spectroscopy [54] (Figure 3b). Therefore, the number and relative intensity of these bands represent pure tremolite and almost pure tremolite (Fe-tremolite) with a small percentage of $\mathrm{Fe}^{2+}$ (Figure 3b,c).

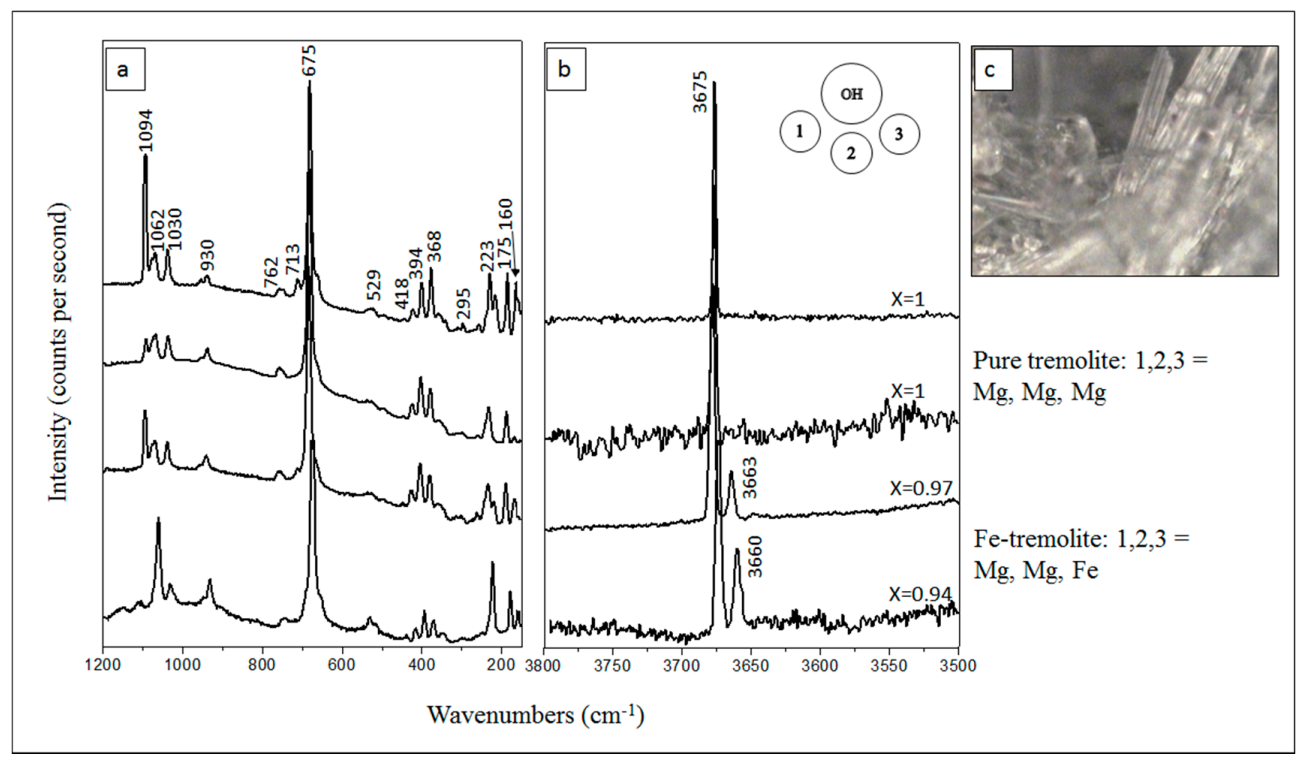

Figure 3. Raman spectra at low (a) and at high (b) wavenumbers of pure Mg-tremolite and Fe-tremolite from selected samples. $\mu$-Raman Spectroscopy image of the fibrous tremolite (c) performed on rock slabs. 
In fact, as reported by $[51,52], X$ value can be estimate from Raman spectra considering: $\mathrm{X}=\left(\mathrm{A}_{12}\right) /\left(1 / 3+\mathrm{A}_{12}\right)$, where $\mathrm{A}_{12}$ is the ratio between the areas of $\mathrm{OH}$ Raman bands at about 3675 and $3660 \mathrm{~cm}^{-1}$. In Figure $3 \mathrm{~b}$, is reported the composition (X value) estimated by using areas of the $\mathrm{OH}$ bands. The presence of $\mathrm{Fe}^{2+}$ is confirmed by the FT-IR spectrum (Figure 4).

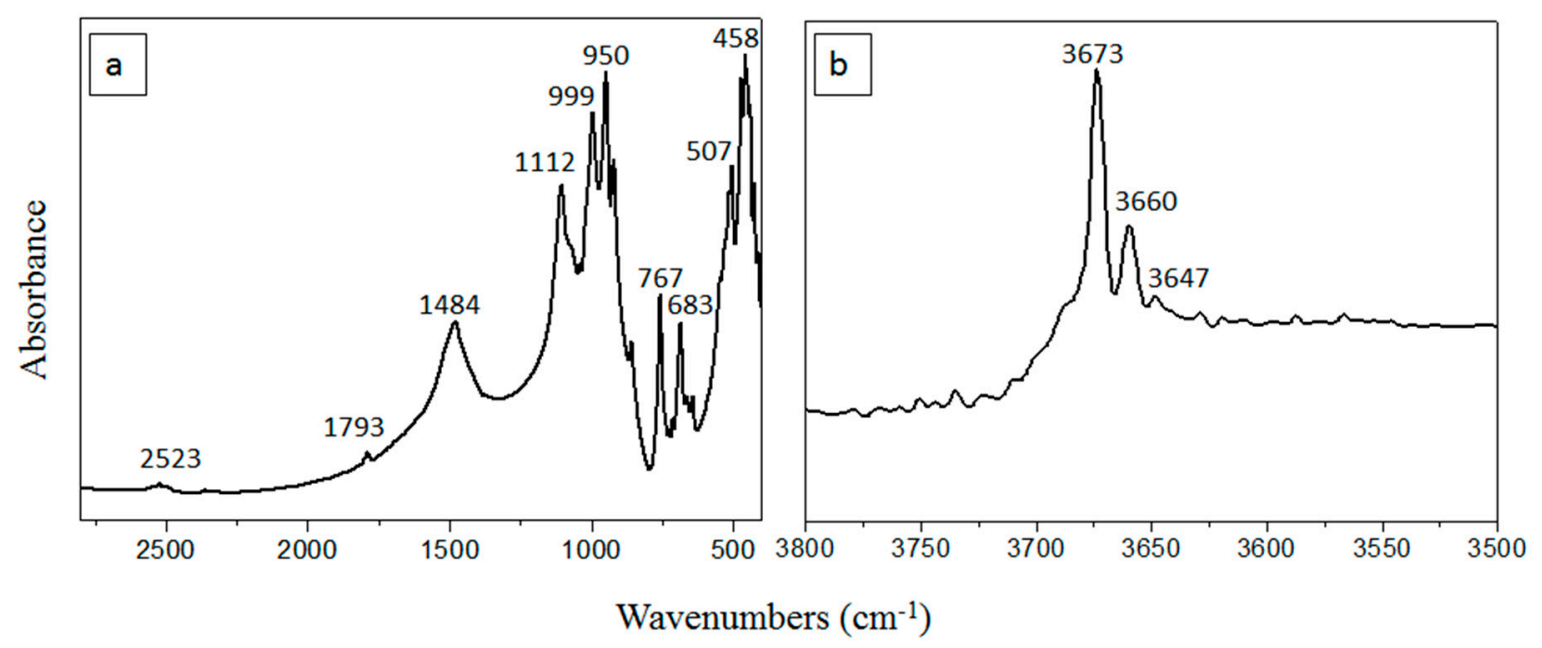

Figure 4. Fourier Transform InfraRed Spectroscopy (FT-IR) spectrum at low (a) and at height (b) wavenumbers.

Site scattering at $\mathrm{M}(1), \mathrm{M}(2)$ and $\mathrm{M}(3)$ sites indicates the presence of $\mathrm{Mg}$ and $\mathrm{Fe}^{2+}$ as observed by [46] for the tremolite and ferro-actinolite and [55] for tremolite from the Susa Valley. In addition to the typical absorption band at $3675-3673 \mathrm{~cm}^{-1}$ assigned to the vibration of the O-H dipole that was bonded to three $\mathrm{Mg}$ cations and arrangement $\left.{ }^{\mathrm{M}(1)} \mathrm{Mg}{ }^{\mathrm{M}(1)} \mathrm{Mg}{ }^{\mathrm{M}(3}\right) \mathrm{Mg}$, which is a prominent band, is observed at $3660 \mathrm{~cm}^{-1}$ and a very weak band at $3647 \mathrm{~cm}^{-1}$ (Figure $4 \mathrm{~b}$ ), both of which were attributed to $\mathrm{M}(1)+\mathrm{M}(3) \mathrm{Fe}^{2+}[45,56]$. $\mathrm{Fe}^{3+}$ was allocated exclusively to $\mathrm{M}(2)$, owing to the absence of absorption bands at $\Delta=50 \mathrm{~cm}^{-1}$ from the tremolite reference band in the FT-IR spectrum [55,57,58] possibly indicating the presence of ${ }^{\mathrm{M}(1)+\mathrm{M}(3)} \mathrm{Fe}^{3+}$. The EMPA on fibre bundles showed the chemical homogeneity of the fibres, with a mean composition of tremolite (Table 2, Figure 5).

Table 2. Chemical composition obtained by electron microprobe analyses (30 analytical points) and min-max range of fibrous tremolite.

\begin{tabular}{ccc}
\hline Oxides & wt $\%$ & Range \\
\hline $\mathrm{SiO}_{2}$ & 52.25 & $45.13-59.36$ \\
$\mathrm{TiO}_{2}$ & 1.25 & $0.50-2.00$ \\
$\mathrm{Al}_{2} \mathrm{O}_{3}$ & 8.65 & $1.84-15.46$ \\
$\mathrm{Cr}_{2} \mathrm{O}_{3}$ & 0.77 & -1.41 \\
$\mathrm{MgO}$ & 20.81 & $14.97-26.66$ \\
$\mathrm{CaO}$ & 16.18 & $7.97-24.39$ \\
$\mathrm{MnO}$ & 0.10 & $0.00-0.21$ \\
$\mathrm{FeO}_{\text {tot }}$ & 3.76 & $2.47-5.06$ \\
$\mathrm{Fe}_{2} \mathrm{O}_{3}$ & n.d. & n.d. \\
$\mathrm{Na}_{2} \mathrm{O}$ & 0.98 & $0.05-1.91$ \\
$\mathrm{~K}_{2} \mathrm{O}$ & 0.60 & $0.56-0.64$ \\
\hline
\end{tabular}

n.d.: not detected 


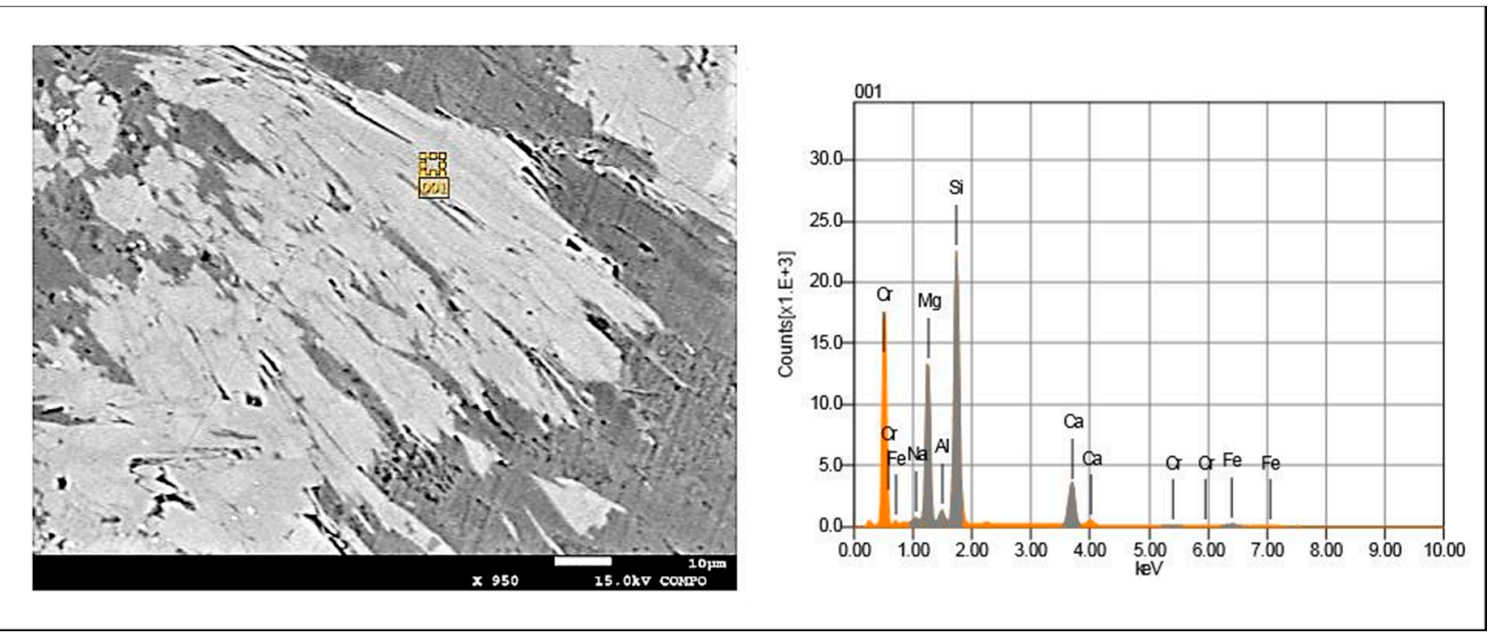

Figure 5. Secondary-electron image (SEI) of the fibrous tremolite and relative spectrum of the fibres.

This is confirmed by the absence of relevant peak broadening and/or asymmetry of the X-ray powder diffraction pattern (Figure 5). The analyses were normalized to 23 oxygens, and the cations were distributed according to the crystal-chemical formula $\mathrm{AB}_{2} \mathrm{C}_{5}\left[\mathrm{~T}_{8} \mathrm{O}_{22} /(\mathrm{OH})_{2}\right](\mathrm{A}=$ vacant; $\mathrm{B}=\mathrm{Ca}$, $\mathrm{Mg} ; \mathrm{C}=\mathrm{Mg}, \mathrm{Al} ; \mathrm{T}=\mathrm{Al}, \mathrm{Si}$ ). The EMPA results (Table 2) shows differences between $\mathrm{MgO}$ and $\mathrm{CaO}$ larger than their standard deviations and are related to the presence of calcite and serpentine, as previously revealed by the XRPD results. The $\mathrm{FeO}_{\text {tot }}$ content varies from 2.47 to $5.06 \mathrm{wt} \%$ and is not related to the Ca content. This fact seems to indicate the absence of a Ca- $\mathrm{Fe}^{2+}$ substitution scheme according to the results of [55]. The EMP analyses revealed that the average composition that was obtained on single crystals is clearly distinguished from the typical compositions of the tremolite, in particular our samples show high content of $\mathrm{Al}_{2} \mathrm{O}_{3}(1.84-15.46 \mathrm{wt} \%)$ and $\mathrm{FeO}(2.47-5.06 \mathrm{wt} \%)$ with a small percentage of $\mathrm{Cr}_{2} \mathrm{O}_{3}(0.13-1.41 \mathrm{wt} \%), \mathrm{TiO}_{2}$ (0.50-2.00), and $\mathrm{Na}_{2} \mathrm{O}$ (0.05-1.91) (Table 2). The scanning electron microscope equipped with electron-dispersive spectroscopy (SEM-EDS) shows that crystals are homogeneous, without zoning, although some crystals show variations compositions of $\mathrm{SiO}_{2}$, $\mathrm{CaO}, \mathrm{MgO}, \mathrm{Fe}_{2} \mathrm{O}_{3}, \mathrm{Al}_{2} \mathrm{O}_{3}$, and $\mathrm{Na}_{2} \mathrm{O}$ in the rim and core (Table 3). Finally, it is difficult to evaluate within serpentinites the amount of each fibrous phase by different analytical techniques used, since amphiboles with asbestiform habit are typically intergrown with serpentine minerals.

Table 3. Chemical composition obtained by SEM (15 analytical points) and variations compositions in the rim and core of fibrous tremolite.

\begin{tabular}{ccccc}
\hline Oxides & $(\mathbf{w t} \%)$ & Rim $\mathbf{( w t} \%)$ & Core $(w \mathbf{~} \%)$ & Apfu \\
\hline $\mathrm{SiO}_{2}$ & 56.87 & 57.89 & 57.66 & 8.09 \\
$\mathrm{Al}_{2} \mathrm{O}_{3}$ & 3.47 & 5.05 & 3.86 & 0.28 \\
$\mathrm{Cr}_{2} \mathrm{O}_{3}$ & 0.23 & n.d. & n.d. & 0.05 \\
$\mathrm{MgO}$ & 25.56 & 24.89 & 21.77 & 5.14 \\
$\mathrm{CaO}$ & 15.11 & 12.69 & 14.54 & 1.85 \\
$\mathrm{Fe}_{2} \mathrm{O}_{3}$ & 2.93 & n.d. & n.d. & n.d. \\
$\mathrm{Na}_{2} \mathrm{O}$ & 1.50 & 3.21 & 2.83 & 0.30 \\
$\mathrm{~K}_{2} \mathrm{O}$ & n.d. & 2.15 & 0.39 & 0.33 \\
\hline
\end{tabular}

n.d.: not detected

\section{Conclusions}

In this study, cataclastic asbestos-bearing serpentinites were studied by several analytical methods. The research focussed on serpentinite rocks that widely outcrop in the southern Apennine in natural outcrops, as well as in active and abandoned quarries, and result from serpentinization processes 
that have involved green-bluish mantle peridotites of Neotethys oceanic basin. Mineralogical results indicate the asbestiform tremolite and serpentine polimorphous [51], as the main mineralogical components of serpentinites, followed by actinolite and other potentially harmful amphiboles that currently are not regulated by the Directive 2003/18/EC of the European Parliament and of the European Council of 27th March 2003. $\mu$-Raman spectroscopy showed pure tremolite $(\mathrm{Mg}, \mathrm{Mg}, \mathrm{Mg})$ and almost pure tremolite (Fe-tremolite) in the serpentinites.

Determined iron species are connected with the biological reactivity of the different fibre types $[56,59,60]$. The "ideal" tremolite fibre is magnesium rich and free of iron [13], but small amounts of iron may substitute for magnesium in the crystalline structure of tremolite [10], in the octahedral site. Therefore, the crystal-chemical characterization of fibrous amphiboles is extremely relevant for environmental and health issues. In this study was reported the presence of $\mathrm{FeO}_{\text {tot }}(2.47-5.06 \mathrm{wt} \%)$ and $\mathrm{Fe}_{2} \mathrm{O}_{3}(2.07-3.78 \mathrm{wt} \%)$ in tremolite asbestos samples from Calabria-Lucanian boundary. The presence of Fe to ideal chemical composition in tremolite asbestos, even in small amounts is considerable to be responsible for the pathological effects for the human living in this area. In fact, studies focusing on the interactions between broncho-alveolar fluids and inhaled atmospheric particulate [26,27], pointed out that, as a consequence of partial or total dissolution, metallic elements are released and accumulate in the human organs, inducing different health effects [28]. Furthermore, the data on analyzed samples reveal that these fibres show a size that, according to several authors [61-63], may be significantly associated with carcinogenesis when breathed. It is important to point out that the size of the fibres may depend on excavation works or because they tend to split up along their elongation axis, and that fibres shorter than $1.5 \mu \mathrm{m}$ could also be further associated with carcinogenic lung cancer [64,65]. The mobilizable of Fe, for some authors [8,23], with the other factors as size, shape, etc., play a role in amphibole asbestos-induced toxicity. The mobilizable on the surface iron could be mainly responsible for amphibole asbestos-induced ROS toxicity [66,67].

Though the toxicity is related to the Fe content in the fibers, it is also necessary to emphatisize that the role played by trace metals including $\mathrm{Mn}, \mathrm{Cr}, \mathrm{Co} ., \mathrm{Ni}, \mathrm{Cu}, \mathrm{Zn}$, since these elements may promote the lung cancer [2].

For this reason, serpentinites should be prudentially analyzed before their employment for building purposes assuming as crucial the geo-scientist role.

A further step could concern the concentration of trace elements in asbestos-like minerals occurring in ophiolitic rocks in the Pollino Massif.

Our findings thus improve the knowledge about the naturals sites, especially at the Calabria-Lucanian boundary, furnishing to the interested stakeholders a useful tool for planning best practices.

When considering the results that were obtained on the asbestos minerals occurring in ophiolitic rocks in the Pollino Geopark, the preparation of a GIS map in the area should be planned, also considering the incident mesothelioma cases, in order to obtain an accurate and complete lifetime residential and occupational histories. Works in progress would to develop a model to evaluate relationship between actual environmental exposure to NOA and major influencing factors, and to develop public health strategies to reduce exposure to asbestos from environmental sources.

Acknowledgments: The authors benefited from finance support by University of Basilicata research funds.

Author Contributions: Maria Carmela Dichicco: $\mu$-Raman Spectroscopy and Fourier Transform Infrared Spectroscopy analysis and interpretation. Salvatore Laurita: geological background and field geology. Rosa Sinisi: X-ray powder diffraction analysis and interpretation. Raimondo Battiloro: toxicological support. Giovanna Rizzo: Scanning Electron Microscopy and Electron Microprobe analysis and interpretation. All authors contributed to write the article.

Conflicts of Interest: The authors declare no conflict of interest. 


\section{References}

1. Bloise, A.; Catalano, M.; Critelli, T.; Apollaro, C.; Miriello, D. Naturally occurring asbestos: Potential for human exposure, San Severino Lucano (Basilicata, Southern Italy). Environ. Earth Sci. 2017, 76, 648. [CrossRef]

2. Bloise, A.; Barca, D.; Gualtieri, A.F.; Pollastri, S.; Belluso, E. Trace elements in hazardous mineral fibres. Environ. Pollut. 2016, 216, 314-323. [CrossRef] [PubMed]

3. Margiotta, S.; Mongelli, G.; Paternoster, M.; Summa, V.; Fiore, S. Trace element distribution and Cr(VI) speciation in $\mathrm{Ca}-\mathrm{HCO}_{3}$ and $\mathrm{Mg}-\mathrm{HCO}_{3}$ spring waters from the northern sector of the Pollino massif, southern Italy. J. Geochem. Explor. 2012, 115, 1-12. [CrossRef]

4. Mossman, B.T.; Lippmann, M.; Hesterberg, T.W.; Kelsey, K.T.; Barchowsky, A.; Bonner, J.C. Pulmonary Endpoints (Lung Carcinomas and Asbestosis) Following Inhalation Exposure to Asbestos. J. Toxicol. Environ. Health Part B 2011, 14, 76-121. [CrossRef] [PubMed]

5. Brody, A.R. Asbestos and lung disease. Am. J. Respir. Cell Mol. Biol. 2010, 42, 131-132. [CrossRef] [PubMed]

6. Jamrozik, E.; de Klerk, N.; Musk, A.W. Asbestos-related disease. Internal Med. J. 2011, 41, 372-380. [CrossRef] [PubMed]

7. Liu, G.; Cheresh, P.; Kamp, D.W. Molecular basis of asbestos-induced lung disease. Annu. Rev. Pathol. 2013, 8, 161-187. [CrossRef] [PubMed]

8. Stayner, L.; Welch, L.S.; Lemen, R. The worldwide pandemic of asbestos-related diseases. Annu. Rev. Public Health 2013, 34, 205-216. [CrossRef] [PubMed]

9. Gunter, M.E. Asbestos as a metaphor for teaching risk perception. J. Geol. Educ. 1994, 42, 17-24. [CrossRef]

10. Virta, R.L. Mineral Commodity Profiles: Asbestos; USGS Circular 1255-KK; US Geological Survey (USGS): Reston, Virginia, USA, 2005; p. 56.

11. Hawthorne, F.C.; Oberti, R. Amphiboles: Crystal Chemistry. Rev. Mineral. Geochem. 2007, 67, 1-54. [CrossRef]

12. Roth, P. Minerals First Discovered in Switzerland and Minerals Named after Swiss Individual; Excalibur Mineral Corp.: Charlottesville, VA, USA, 2007.

13. Leake, B.E.; Woolley, A.R.; Arps, C.E.S.; Birch, W.D.; Gilbert, M.C.; Grice, J.D.; Hawthorne, F.C.; Kato, A.; Kisch, H.J.; Krivovichev, V.G.; et al. Report. Nomenclature of Amphiboles: Report of Amphiboles: Report of the subcommittee on Amphiboles of the International Mineralogical Association Commission on New Minerals and Mineral Names. Mineral. Mag. 1997, 61, 295-321. [CrossRef]

14. Baumann, F.; Buck, B.J.; Metcalf, R.V.; McLaurin, B.T.; Merkler, D.J.; Carbone, M. The Presence of Asbestos in the Natural Environment is Likely Related to Mesothelioma in Young Individuals and Women from Southern Nevada. J. Thorac. Oncol. 2015, 10, 731-737. [CrossRef] [PubMed]

15. Pasetto, R.; Bruni, B.; Bruno, C.; D’Antona, C.; De Nardo, P.; Di Maria, G.; Di Stefano, R.; Fiorentini, C.; Gianfagna, A.; Marconi, A.; et al. Problematiche sanitarie della fibre anfibolica di Biancavilla. Aspetti epidemiologici, clinici e sperimentali. Notiziario dell'Istituto Superiore di Sanità 2004, 17, 8-12.

16. Massaro, T.; Fiore, S.; Dragonieri, S.; Grimaldi, M.C.; Pistillo, S.; Cauzzillo, G.; Musti, M. Pleura malignant mesothelioma among resident population in areas with natural occurring asbestos on Calabria-lucania border. In Proceedings of the GeoMed-4th International Conference on Medical Geology, Bari, Italy, 20-25 September 2011.

17. Ripabelli, G.; Tamburro, M.; Di Tella, D.; Carrozza, F.; Sammarco, M.L. Asbestos Exposures, Mesothelioma Incidence and Mortality, and Awareness by General Practitioners in the Molise Region, Central Italy. J. Occup. Environ. Med. 2018, 60, e90-e97. [CrossRef] [PubMed]

18. Baris, Y.I.; Sahin, A.A.; Ozesmi, M.; Kerse, I.; Ozen, E.; Kolacan, B. An outbreak of pleural mesothelioma and chronic fibrosing pleurisy in the village of Krain/Urgüp in Anatolia. Thorax 1978, 33, 181-192. [CrossRef] [PubMed]

19. Bloise, A.; Barrese, E.; Apollaro, C. Hydrothermal alteration of Ti-doped forsterite to chrysotile and characterization of the resulting chrysotile fibres. Neues Jahrb. Miner. Abh. 2009, 185, 297-304. [CrossRef]

20. Bloise, A.; Belluso, E.; Barrese, E.; Miriello, D.; Apollaro, C. Synthesis of Fe-doped chrysotile and characterization of the resulting chrysotile fibers. Cryst. Res. Technol. 2009, 44, 590-596. [CrossRef]

21. Bloise, A.; Belluso, E.; Fornero, E.; Rinaudo, C.; Barrese, E.; Capella, S. Influence of synthesis condition on growth of Ni-doped chrysotile. Microporous Mesoporous Mater. 2010, 132, 239-245. [CrossRef]

22. Spadea, P. Calabria-Lucania ophiolites. B Geofis. Teori. Appl. 1994, 36, 271-281. 
23. Fubini, B.; Otero-Arean, C. Chemical aspects of the toxicity of invale mineral dusts. Chem. Soc. Rev. 1999, 28, 373-381. [CrossRef]

24. Loreto, C.; Carnazza, M.L.; Cardile, V.; Libra, M.; Lombardo, L.; Malaponte, G.; Martinez, G.; Musumeci, G.; Papa, V.; Cocco, L. Mineral fiber-mediated activation of phosphoinositide-specific phospho-lipasec in human bronchoalveolar carcinoma-derived alveolar epithelial A549 cells. Int. J. Oncol. 2009, 34, 371-376. [PubMed]

25. Pugnaloni, A.; Giantomassi, F.; Lucarini, G.; Capella, S.; Bloise, A.; Di Primio, R.; Belluso, E. Cytotoxicity induced by exposure to natural and synthetic tremolite asbestos: An in vitro pilot study. Acta Histochem. 2013, 115, 100-112. [CrossRef] [PubMed]

26. Censi, P.; Tamburo, E.; Speziale, S.; Zuddas, P.; Randazzo, L.A.; Punturo, R.; Cuttitta, A.; Aricò, P. Yttrium and lanthanides in human lung fluids, probing the exposure to atmospheric fallout. J. Hazard. Mater. 2011, 186, 1103-1110. [CrossRef] [PubMed]

27. Censi, P.; Zuddas, P.; Randazzo, L.A.; Tamburo, E.; Spezial, S.; Cuttitta, A.; Punturo, R.; Aricò, P.; Santagata, R. Source and nature of inhaled atmospheric dust from trace element analyses of human bronchial fluids. Environ. Sci. Technol. 2011, 45, 6262-6267. [CrossRef] [PubMed]

28. Nordberg, G.F.; Nogawa, K.; Nordberg, M.; Friberg, L.T. Handbook on the Toxicology of Metals, 3rd ed.; Academic Press/Elsevier: London, UK, 2007; Volume 23, pp. 446-486.

29. Langer, A.M.; Nolan, R.P.; Constantopoulos, S.H.; Moutsopoulos, H.M. Association of Metsovo lung and pleural mesothelioma with exposure to tremolite containing whitewash. Lancet 1987, 1, 965-967. [CrossRef]

30. McConnochie, K.; Simonato, L.; Mavrides, P.; Christofides, P.; Pooley, F.D.; Wagner, J.C. Mesothelioma in Cyprus: The role of tremolite. Thorax 1987, 42, 342-347. [CrossRef] [PubMed]

31. Luo, S.; Liu, X.; Mu, S.; Tsai, S.P.; Wen, C.P. Asbestos related diseases from environmental exposure to crocidolite in Da-yao, China I. Review of exposure and epidemiological data. Occup. Environ. Med. 2003, 60, 35-41. [CrossRef] [PubMed]

32. Verkounteren, J.R.; Wylie, A.G. The tremolite-actinolite-ferro-actinolite series: Systematic relationships among cell parameters, composition, optical properties, and habit, and evidence of discontinuities. Am. Miner. 2000, 85, 1239-1254. [CrossRef]

33. Skogby, H.; Rossman, G.R. The intensity of amphibole OH bands in the Infrared absorption spectrum. Phys. Chem. Miner. 1991, 18, 64-68. [CrossRef]

34. Spadea, P. Continental crust rocks associated with ophiolites in Lucanian Apennine (southern Italy). Ofioliti 1982, 7, 501-522.

35. Mongelli, G.; Dinelli, E. The geochemistry of shales from the "Frido Unit", Liguride complex, lucanian Apennines, Italy: Implications for provenance and tectonic setting. Ofioliti 2001, 26, 457-466.

36. Laurita, S.; Prosser, G.; Rizzo, G.; Langone, A.; Tiepolo, M.; Laurita, A. Geochronological study of zircons from continental crust rocks in the Frido Unit (southern Apennines). Int. J. Earth Sci. 2014, 104, 179-203. [CrossRef]

37. Rizzo, G.; Sansone, M.T.C.; Perri, F.; Laurita, S. Mineralogy and petrology of the metasedimentary rocks from the Frido Unit (southern Apennines, Italy). Period. Mineral. 2016, 85, 153-168.

38. Knott, S.D. The Liguride Complex of southern Italy a Cretaceous to Paleogene accretionary wedge. Tectonophysics 1987, 142, 217-243. [CrossRef]

39. Knott, S.D. Structure, kinematics and metamorphism in the Liguride Complex, Southern Apennine, Italy. J. Struct. Geol. 1994, 16, 1107-1120. [CrossRef]

40. Monaco, C.; Tortorici, L.; Morten, L.; Critelli, S.; Tansi, C. Geologia del versante Nord-orientale del Massiccio del Pollino (Confine calabro lucano). Nota illustrativa sintetica alla scala 1:50.000. Boll. Soc. Geol. Ital. 1995, 114, 277-291.

41. Monaco, C.; Tortorici, L. Tectonic role of ophiolite-bearing terranes in building of the Southern Apennines orogenic belt. Terra Nova 1995, 7, 153-160. [CrossRef]

42. Rizzo, G.; Laurita, S.; Altenberger, U. The Timpa delle Murge ophiolitic gabbros, southern Apennines: Insights from petrology and geochemistry and consequences to the geodynamic setting. Period. Mineral. 2017, 86. [CrossRef]

43. Sansone, M.T.C.; Prosser, G.; Rizzo, G.; Tartarotti, P. Spinel-peridotites of the Frido Unit ophiolites (southern ApenninesH Italy): Evidence for oceanic evolution. Period. Mineral. 2012, 81, 35-59. 
44. Sansone, M.T.C.; Tartarotti, P.; Prosser, G.; Rizzo, G. From ocean to subduction: The polyphase metamorphic evolution of the Frido Unit metadolerite dykes (Southern Apennine, Italy). J. Virtual Explor. 2012, 41. [CrossRef]

45. Gueguen, E.; Doglioni, C.; Fernandez, M. On the post-25 Ma geodynamic evolution of the western Mediterranean. Tectonophysics 1998, 298, 259-269. [CrossRef]

46. Evaus, B.W.; Yaug, H. Fe-Mg order-disorder in tremolite-actinoliteferro-actinolite at ambient and high temperature. Am. Mineral. 1998, 83, 458-475.

47. Patacca, E.; Scandone, P. Geology of the southern Apennines. In Results of the CROP Project, Sub-Project CROP-04 Southern Apennines (Italy); Mazzotti, A., Patacca, E., Scandone, P., Eds.; Società Geologica Italiana: Bologna, Italy, 2007; pp. 75-119.

48. Sansone, M.T.C.; Rizzo, G. Pumpellyite veins in the metadolerite of the Frido Unit (southern Apennines-Italy). Period. Mineral. 2012, 81, 75-92.

49. Dichicco, M.C.; De Bonis, A.; Mongelli, G.; Rizzo, G.; Sinisi, R. Naturally occurring asbestos in the southern Apennines: Quick $\mu$-Raman Spectroscopy identification as a tool of environmental control. In Proceedings of the Book of Abstracts of the 13th International Conference on Protection and Restoration of the Environment, Mykonos Island, Greece, 3-8 July 2016.

50. Dichicco, M.C.; Laurita, S.; Paternoster, M.; Rizzo, G.; Sinisi, R.; Mongelli, G. Serpentinite Carbonation for $\mathrm{CO}_{2}$ Sequestration in the Southern Apennines: Preliminary Study. Energy Procedia 2015, 76, 477-486. [CrossRef]

51. Dichicco, M.C.; De Bonis, A.; Mongelli, G.; Rizzo, G.; Sinisi, R. $\mu$-Raman spectroscopy and X-ray diffraction of asbestos' minerals for geo-environmental monitoring: The case of the southern Apennines natural sources. Appl. Clay Sci. 2017, 141, 292-299. [CrossRef]

52. Bersani, D.; Andò, S.; Scrocco, L.; Gentile, P.; Salvioli-Mariani, E.; Lottici, P.P. Study of composition of amphiboles in the tremolite-Ferro-actinolite series by micro-Raman and SEM-EDXS. In Proceedings of the 11th International Geo Raman Conference, Louis, MI, USA, 15-19 June 2014; Volume 1783.

53. Siivola, J.; Schmid, R. List of Mineral Abbrevations-Recommendations by the IUGS Subcommission on the Systematics of Metamorphic Rocks. Web Version 01.02.2007. Available online: https:/ /www.bgs.ac.uk/ scmr/products.html (accessed on 8 March 2018).

54. Chen, T.H.; Calligaro, T.; Pagès-Camagna, S.; Menu, M. Investigation of Chinese archaic jade by PIXE and $\mu$ Raman spectrometry. Appl. Phys. A 2004, 79, 177-180. [CrossRef]

55. Ballirano, P.; Andreozzi, G.B.; Belardi, G. Crystal chemical and structural characterization of fibrous tremolite from Susa Valley, Italy, with comments on potential harmful effects on human health. Am. Mineral. 2008, 93, 1349-1355. [CrossRef]

56. Shukla, A.; Gulumian, M.; Hei, T.K.; Kamp, D.; Rahman, Q.; Mossman, B.T. Multiple roles of oxidants in the pathogenesis of asbestos induced diseases. Free Radic. Biol. Med. 2003, 34, 1117-1129. [CrossRef]

57. Raudsepp, M.; Turnock, A.C.; Hawthorne, F.C.; Sherriff, B.K.; Hartmau, J.S. Characterization of synthetic pargasitic amphiboles (NaCa2Mg4M3+Si6Al2,O22(OH,F)2; M3+=Al, Cr, Ga, Sc, In) by infrared spectroscopy, Rietveld structurerefmement, and 27AI,29Si, and 19p: MASNMR spectroscopy. Am. Mineral. 1987, 72, 580-593.

58. Pacella, A.; Ballirano, P. Chemical and structural characterization of fibrous richterite with high environmental and health relevance from Libby, Montana (USA). Period. Mineral. 2016, 85, 169-177.

59. Barlow, C.A.; Barrett, T.F.; Shukla, A.; Mossman, B.T.; Lounsbury, K.M. Asbestos-mediated CREB phosphorylation is regulated by protein kinase A and extracellular signal-regulated kinases $\frac{1}{2}$. Am. J. Physiol. Lung Cell. Mol. Physiol. 2007, 292, L1361-L1369. [CrossRef] [PubMed]

60. Shukla, A.; Jung, M.; Stern, M.; Fukagawa, N.K.; Taatjes, D.J.; Sawyer, D.; Van Houten, B.; Mossman, B.T. Asbestos induces mitochondrial DNA damage and dysfunction linked to the development of apoptosis. Am. J. Physiol. Lung Cell. Mol. Physiol. 2003, 285, L1018-L1025. [CrossRef] [PubMed]

61. Stanton, M.F.; Layard, M.; Tegeris, A.; Miller, E.; May, M.; Morgan, E.; Smith, A. Relation of particle dimension to carcinogenicity in amphibole asbestoses and other fibrous minerals. J. Natl. Cancer Inst. 1981, 67, 965-975. [PubMed]

62. Berman, D.W.; Crump, K.S.; Chatfield, E.J.; Davis, J.M.G.; Jones, A.D. The sizes, shapes, and mineralogy of asbestos structures that induce lung tumors or mesothelioma in AF/HAN rats following inhalation. Risk Anal. 1995, 15, 181-195. [CrossRef] [PubMed] 
63. Bernstein, D.; Castranova, V.; Donaldson, K.; Fubini, B.; Hadley, J.; Hesterberg, T.; Kane, A.; Lai, D.; McConnell, E.E.; Muhle, H.; et al. Testing of fibrous particles: Short-term assays and strategies. Inhal. Toxicol. 2005, 17, 497-537. [CrossRef] [PubMed]

64. Dodson, R.F.; Atkinson, M.A.; Levin, J.L. Asbestos fiber length as related to potential pathogenicity: A critical review. Am. J. Ind. Med. 2003, 44, 291-297. [CrossRef] [PubMed]

65. Loomis, D.; Dement, J.; Richardson, D.; Wolf, S. Asbestos fibre dimensions and lung cancer mortality among workers exposed to chrysotile. Occup. Environ. Med. 2010, 67, 580-584. [CrossRef] [PubMed]

66. Fantauzzi, M.; Pacella, A.; Atzei, D.; Gianfagna, A.; Andreozzi, G.B.; Rossi, A. Combined use of X-ray photoelectron and Mössbauer spectroscopic techniques in the analytical characterization of iron oxidation state in amphibole asbestos. Anal. Bioanal. Chem. 2010, 396, 2889-2898. [CrossRef] [PubMed]

67. Srivastava, R.K.; Lohani, M.; Pant, A.B.; Rahman, Q. Cyto-genotoxicity of amphibole asbestos fibers in cultured human lung epithelial cell line: Role of surface iron. Toxicol. Ind. Health 2010, 26, 575-582. [CrossRef] [PubMed]

(C) 2018 by the authors. Licensee MDPI, Basel, Switzerland. This article is an open access article distributed under the terms and conditions of the Creative Commons Attribution (CC BY) license (http:/ / creativecommons.org/licenses/by/4.0/). 